\title{
The cytotoxicity, anti-inflammation, anti-nociceptive and oral ulcer healing properties of coconut shell liquid smoke
}

\author{
Meircurius Dwi Condro Surboyo ${ }^{1^{*}}{ }^{(\mathbb{D}}$, Fatma Yasmin Mahdani ${ }^{\mathbb{(}}$, Nurina Febriyanti Ayuningtas ${ }^{\mathbb{D}}$, Arvind

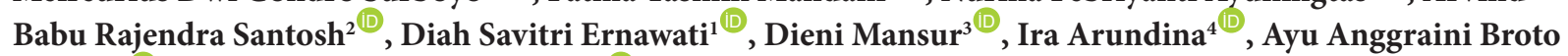 \\ Nagoro $^{5^{\mathbb{D}}}$, Indriasari Putri Rahmadhany ${ }^{5^{\mathbb{D}}}$
}

${ }^{1}$ Department of Oral Medicine, Faculty of Dental Medicine, Universitas Airlangga, Surabaya, Indonesia ${ }^{2}$ School of Dentistry, Faculty of Medical Sciences, The University of The West Indies, Mona, Jamaica

${ }^{3}$ Research Centre for Chemistry, Indonesian Institute of Sciences, Kawasan PUSPIPTEK - Serpong, Tangerang Selatan, Banten, Indonesia ${ }^{4}$ Department of Oral Biology, Faculty of Dental Medicine, Universitas Airlangga, Surabaya, Indonesia

${ }^{5}$ Bachelor of Dental Surgery, Faculty of Dental Medicine, Universitas Airlangga, Surabaya, Indonesia

\section{A R T I C L E I N F 0}

Article Type:

Original Article

Article History:

Received: 19 May 2021

Accepted: 20 July 2021

\section{Keywords:}

Anti-inflammatory

Anti-nociception

Bio-economy

Coconut shell liquid smoke

Cytotoxicity

Oral ulcer

\begin{abstract}
A B S T R A C T
Introduction: Coconut shell liquid smoke (CS-LS) from Cocos nucifera L. has been traditionally used by Indonesians as a natural preservative. Besides that, liquid smoke is also used as a medicine to treat various types of wounds. During the storage, liquid smoke resulting from pyrolysis is still questionable in relation to the oxidation process and changes in its properties and potentials. We observed the physical characteristics, components, toxicity, anti-inflammatory, anti-nociceptive properties, and effect in oral ulcer healing of CS-LS.

Methods: Acidity was analyzed using a digital $\mathrm{pH}$ meter, density test was analyzed using a pycnometer, and the components were determined using gas chromatography mass spectrometry (GC-MS). Eight concentrations of CS-LS (1\%, 2\%, 4\%, 6\%, 8\%, 10\%, 12\%, and $14 \%$ ) were tested on baby hamster kidney (BHK21) for the extract toxicity, carrageenaninduced rat paw edema for its anti-inflammatory properties, hot-plate test for its antinociceptive, and traumatized labial fornix incisive inferior for its oral ulcer healing. Results: The acidity of CS-LS was 2.296 and the density was $1.0102 \mathrm{~g} / \mathrm{mL}$. The major components analyzed were phenol (32.75\%), 2-methoxy-phenol (17.45\%), and furfural (13.09\%). The CS-LS $100 \%$ and CS-LS $8 \%$ were the optimum concentrations for maintaining the BHK21 and increasing the number of fibroblasts in oral ulcer healing. The CS-LS 100\% showed potent anti-nociceptive ability compared to other concentrations $(P=0.001)$, but not for the anti-inflammation properties.

Conclusion: CS-LS is a promising natural herb for oral medicine, especially oral ulcer medicine.
\end{abstract}

Implication for health policy/practice/research/medical education:

This paper provides the properties of coconut shell liquid smoke, and therefore, it might be useful for the treatment of oral ulcers. Please cite this paper as: Surboyo MDC, Mahdani FY, Ayuningtas NF, Santosh ABR, Ernawati DS, Mansur D, et al. The cytotoxicity, anti-inflammation, anti-nociceptive and oral ulcer healing properties of coconut shell liquid smoke. J Herbmed Pharmacol. 2021;10(4):459-467. doi: 10.34172/jhp.2021.53.

\section{Introduction}

Coconut shell liquid smoke (CS-LS) is the bio-economy product, consists of light tar or liquid smoke resulting from the pyrolysis of coconut shell, which has components similar to wood $(1,2)$. The benefits of using CS-LS as a natural preservative are safer food preservation, lower cost, and ease of application in the home industry. The use and application of CS-LS itself as an alternative for food product preservative already exist in Indonesia (2). In recent years, CS-LS has also been explored as a natural remedy for treating human ailments. In a diabetic model, the CS-LS has shown the potential to lower fasting blood 
glucose and maintain body weight (3). The other potential is in treating diabetic oral ulcers through inhibition of macrophage activity (4), production of the tumor necrosis factor-alpha (1), increasing collagen synthesis (5), and induction of oral ulcer healing (3), by increased fibroblast and growth factor (6).

In traditional medicine in Indonesia, it has been used for generations in the health care system (7). Liquid smoke has long been used by Indonesian ancestors to treat skin diseases caused by fungi, viruses, and bacteria by applying it to the affected area (8). Liquid smoke might also be used as an alternative topical agent for treating burn wounds by reducing pain, increasing fibroblast proliferation and capillary formation (9). The use of natural ingredients as traditional medicine in society is increasingly widespread. Research is needed to evaluate its use in accordance with the rules of health service, and it must be accountable scientifically for the quality, safety, and efficacy of traditional medicine (10).

The chemical changes that occur over time may affect the sensory properties of smoke in the generation and use of liquid smoke, which has potential significance in storage of liquid smoke. The lowest sensory score can be found in after-processed liquid smoke, specifically 5 hours after production. However, they gradually improved over time because the methyl alcohol could react with acetic and formic acids to form esters with softer flavors (11). Additional chemical changes will certainly occur during the storage of liquid smoke, which might result in the loss of undesirable or desirable compounds with the development of other flavor-based compounds (11).

The characteristic of after-process CS-LS obtained from the pyrolysis process and purified through distillation has a yellow color, acidity 2.39, and density $1.0643 \mathrm{~g} /$ $\mathrm{mL}$ with major component identified as phenol (36.6\%), 2-methoxy-phenol (25.2\%), and furfural (17.09\%) (2). As a natural preservative, the after-processed CS-LS is not a toxic agent (12), possesses anti-nociceptive (13), antiinflammatory (13), and stimulates the oral ulcer healing by increasing the fibroblast (6), and collagen (5). The production of liquid smoke is not easy and has become a major challenge. During pyrolysis process with a final temperature of $400^{\circ} \mathrm{C}$, coconut shell as raw material, only $32.23 \%$ of liquid smoke and $58 \%$ of charcoal produced (14). During the purification, the amount of liquid smoke produced will be less. Therefore, in addition to the production aspect, storage is also a concern. It is mentioned that the storage of liquid smoke may change its chemical composition and properties (11). Based on these predictions, further analysis of the CS-LS characteristics, such as acidity, density, component, cytotoxicity, and clinical potentials, including the anti-nociceptive and anti-inflammatory properties, should be performed. Because there is a potential loss of CS-LS after storage, as observed in after-process CS-LS, the storage strategy needs focusing. The purpose of this study is to observe the characteristics, cytotoxicity, anti-inflammation, antinociceptive, and ulcer healing properties of CS-LS after storage.

\section{Materials and Methods}

CS-LS production and storage

The coconut shell of Cocos nucifera L. was collected from the local market in Tembok Dukuh Surabaya (latitude: $7.2520962^{\circ} \mathrm{S}$, longitude: $\left.112.7177336^{\circ} \mathrm{E}\right)$. The sample was identified by Purwodadi Botanic Garden, Indonesia Institute of Science and identified as species of Cocos nucifera L. The plant name was also verified at http:// www.theplantlist.org (accessed November 29, 2016).

CS-LS from coconut shells was obtained through a pyrolysis process. Five kilograms of dried coconut shells were used. The pyrolysis furnace was equipped with a kerosene pump stove and an encircling reactor with a diameter and height of $30 \mathrm{~cm}$ and $40 \mathrm{~cm}$, respectively. The furnace was connected to the cooling tubes to condense the fumes and generate liquid smoke. Pyrolysis was carried out at a temperature of $400^{\circ} \mathrm{C}$ with a heating rate of $3.33^{\circ} \mathrm{C}$ for 4.5 hours (3). CS-LS was made in Forest Products Research and Development Center Laboratory, Bogor, in 2016 and then stored at a stable temperature at $5^{\circ} \mathrm{C}$.

\section{CS-LS characteristics}

Acidity was analyzed using a digital $\mathrm{pH}$ meter (Mettler Toledo S220, Malaysia). The density was analyzed using a pycnometer (Brand, Germany). The components were determined using gas chromatography-mass spectrometry (GC-MS) model 6890N (Agilent Technologies, Inc., Santa Clara, CA), equipped with a mass spectrometer detector 5975B and DB-5MS UI column (Agilent Technologies, stationary phase; polyethylene glycol, $30 \mathrm{~m} \times 0.25 \mathrm{~mm}$; i.d. $0.25 \mu \mathrm{m})(1)$.

\section{CS-LS concentration}

CS-LS obtained from the pyrolysis process was considered as CS-LS $100 \%$. CS-LS was prepared in eight different concentrations $(1 \%, 2 \%, 4 \%, 6 \%, 8 \%, 10 \%, 12 \%$, and $14 \%)$ diluted by sterile water $(\% \mathrm{v} / \mathrm{v})$.

\section{Cytotoxicity test}

Baby hamster kidney (BHK-21) cells were cultivated in a roux bottle and harvested with Trypsin-Versene solution. BHK-21 cells were inserted into 96 wells microplate, added with D-MEM media containing $10 \%$ fetal bovine serum albumin and incubated at $37^{\circ} \mathrm{C}$ for 24 hours.

Eight concentrations of CS-LS (1\%, 2\%, 4\%, 6\%, $8 \%$, $10 \%, 12 \%, 14 \%, 100 \%)$ were added into 96 microplate wells. Each concentration replicated 8 times. The microplate wells were then incubated for 24 hours, and after 24 hours, each well was added a solution containing MTT reagent in phosphate buffer saline (PBS), then re-incubated for 6 hours. Furthermore, to each well was added dimethyl sulfoxide (DMSO) and shaken with a plate shaker. The 
wells would be read at Elisa Reader in 620 wavelengths. The calculation results are said to be non-toxic if $\geq 60 \%$ of cells be live. The percentage of the live cells was calculated by the formula (15):

$$
\% \text { live cell }=\frac{(\text { test group }+ \text { test } \text { media }) \times 100}{\text { cell }+ \text { media }}
$$

Information:

\% live cells: optical density for each sample

Test group: optical density after each test

Media: optical density on the average of each media control

Cell: optical density on average of cell control

\section{Anti-inflammatory properties}

The anti-inflammatory properties of the CS-LS were observed by the carrageenan-induced rat paw edema test. Forty healthy male Rattus norvegicus rats weighing 110-120 g, 3-4-month-old were used. Animals were divided into 10 groups and each consisted 4 animals. The animals were acclimatized under normal environmental conditions for a few days before starting the experiments (temperature $20-22^{\circ} \mathrm{C}$ and 12 -hour dark/12-hour light cycle).

The first group served as control and received normal saline solution ( $10 \mathrm{~mL} / \mathrm{kg}$, p.o). The second group received indomethacin (10 mg/kg, p.o) suspended as the standard medication in normal saline solution $(0.9 \% \mathrm{w} / \mathrm{v})$. The other eight groups received the CS-LS $1 \%, 2 \%, 4 \%, 6 \%$, $8 \%, 10 \%, 12 \%, 14 \%$, and $100 \%$ (10 mL/kg, p.o).

One hour after oral administration, all animals were injected with $0.1 \mathrm{~mL}$ of $1 \%(\mathrm{v} / \mathrm{v})$ carrageenan solution into saline at the right hind paw sub-plantar region. The paw volume of each rat was measured using a digital caliper before the carrageenan injection and then at 15 minutes intervals up to 1 hour after carrageenan administration. The volume of each rat paw was measured before carrageenan injection using a digital caliper and then at intervals of 15 minutes to 1 hour after carrageenan administration. The percentage of edema was determined for each category as follows:

$\operatorname{Edema}(\%)=\left(V_{t}-V_{0}\right) / V_{0} \times 100$

\section{Information:}

$\mathrm{V}_{0 \text { : }}$ the volume before carrageenan injection ( $\mathrm{mm}$ )

$\mathrm{V}_{\mathrm{t}}$ : the volume at $\mathrm{t}$ minutes after carrageenan injection $(\mathrm{mm})$.

\section{Anti-nociceptive properties}

A hot-plate method was performed for anti-nociceptive properties. A total of 40 adult male Mus musculus mice, weighing 20-30 g were used and divided into 10 groups of 4 animals each. The animals were acclimatized under normal environmental conditions for a few days before starting the experiments (temperature $20-22^{\circ} \mathrm{C}$ and 12 hour dark/12-hour light cycle).

The first group was controlled and received normal saline solution $(10 \mathrm{~mL} / \mathrm{kg}$, i.p). The second group was treated orally with tramadol (40 mg/kg.i.p) as normal medication dissolved in saline solution $(0.9 \% \mathrm{w} / \mathrm{v})$. The other eight groups received the CS-LS $1 \%, 2 \%, 4 \%, 6 \%, 8 \%$, $10 \%, 12 \%, 14 \%$, and $100 \%$ (10 mL/kg, p.o), respectively.

The rats were accustomed to the hot-plate for 3 consecutive days prior to the experiment by putting them on a plate that was held at room temperature for 15 minutes. To carry out the test, every animal was put on a $52^{\circ} \mathrm{C}$ hot-plate daily. Latency to exhibit nociceptive responses, such as licking paws, was determined 30, 45, and 60 minutes after the test substances or saline was administered. Prior to the administration of the standard medication and tested substance, the reaction time for thermal pain was measured. A cut-off time for a response to the thermal stimulus was set at 60 seconds to avoid tissue damage of the rat paws.

\section{Oral ulcer healing}

Twenty-one male Rattus norvegicus rats, weighed around $120-160 \mathrm{~g}$ were used as animal models. A $10 \mathrm{~mm}$ oral ulcer was created using a round stainless blade, in the labial fornix incisive inferior, after anesthetizing the animals, using a combination of xylazine and ketamine. After 24 hours, the oral ulcer appeared as white color surrounded by erythematous area. At this point, the treatment of CSLS $8 \%$ and CS-LS $100 \%$ were performed at a dose of 1 $\mu \mathrm{L} / \mathrm{g}$ weight once a day on the oral ulcer for three, five, and seven days (3).

\section{Statistical analysis}

Statistical analysis for all tests was performed using oneway analysis of variance (ANOVA) sequentially followed by LSD post hoc test using SPSS software, version 24.0 for Mac (SPSS, Inc.). Data are represented as the mean and standard deviation. A $P<0.01$ was considered to be significant.

\section{Results}

CS-LS characteristic

CS-LS had a yellow color. The acidity of CS-LS was 2.296 and density was $1.0102 \mathrm{~g} / \mathrm{mL}$. After long-term storage, CS-LS was identified as having 14 components (Figure $1)$. The major component analyzed in GC-MS was phenol (32.75\%), 2-methoxy-phenol (guaiacol) (17.45\%), and furfural $(13.09 \%)$. Other compounds such as creosol (6.14\%), 2-methyl-phenol (4.23\%), 4-ethyl-2-methoxyphenol (2-EMP) (4.61\%), and 16-Hentriacontanone $(4.62 \%)$ were also be found (Table 1$)$.

\section{Cytotoxicity test}

The highest living cells were observed in CS-LS 100\% (68.08\%) and CS-LS 8\% (60.64\%). The lowest living 


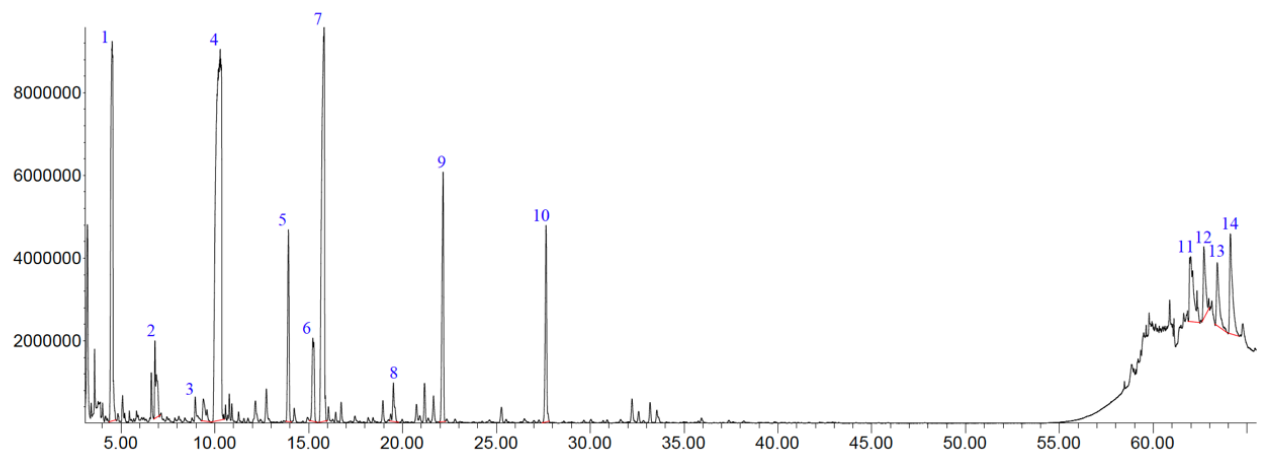

Figure 1. Gas chromatography mass spectrometry (GC-MS) profile of coconut shell of liquid smoke. Peak data are listed in Table 1.

cells of BHK-21 were observed in CS-LS 1\% (36.95\%). The increased number of living cells was followed by an increase in the CS-LS concentration of $1 \%$ until $8 \%$, then decreased until to a concentration of $12 \%$ (Figure 2).

\section{Anti-inflammatory properties}

The effect of CS-LS in carrageenan-induced paw edema is presented in Table 2. The CS-LS in lowest concentration (CS-LS 1\%) until highest concentration showed no difference between indomethacin and control in 15 minutes $(P=0.935), 45$ minutes $(P=0.984)$, and 60 minutes $(P=1.000)$.

\section{Anti-nociceptive properties}

The anti-nociceptive effect of CS-LS in the hotplate method is presented in Table 3. CS-LS showed a lower thermal pain reaction compared with tramadol. CS-LS $1 \%, 4 \%$, $6 \%$, and $8 \%$ showed lower licking behavior compared to tramadol $(P=0.001)$ after 30 minutes administration. The CS-LS 100\% had higher thermal pain reaction compared to CS-LS $1 \%-8 \%(P=0.001)$.

Table 1. Component analysis of coconut shell of liquid smoke by gas chromatography mass spectrometry (GC-MS)

\begin{tabular}{lcc}
\hline Name & Area (\%) & RT \\
\hline Furfural & 13.09 & 4,526 \\
1-(2-furanyl)-ethanone & 2.33 & 6,809 \\
5-methyl-2-Furancarboxaldehyde & 1.01 & 9,392 \\
Phenol & 32.75 & 10,287 \\
2-methyl-phenol & 4.32 & 13,921 \\
p-Cresol & 2.85 & 15,222 \\
2-methoxy-phenol & 17.54 & 15,829 \\
2,4-dimethyl-phenol & 1.15 & 19,514 \\
Creosol & 6.14 & 22,160 \\
4-ethyl-2-methoxy-phenol & 4.61 & 27,645 \\
16-Hentriacontanone & 4.52 & 61,981 \\
16-Hentriacontanone & 2.63 & 62,694 \\
16-Hentriacontanone & 2.68 & 63,407 \\
16-Hentriacontanone & 4.38 & 64,101 \\
\hline
\end{tabular}

After 45 minutes administration, the CS-LS 1\%, 2\%, 4\%, and $6 \%$ showed a lower thermal pain reaction compared with tramadol $(P=0.001)$. The CS-LS $100 \%$ had a higher thermal pain reaction compared to CS-LS $1 \%-8 \%$ $(P=0.001)$.

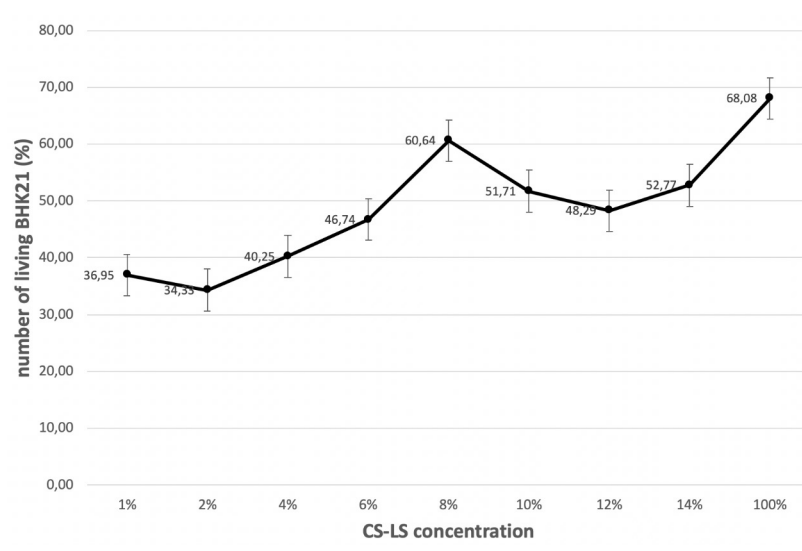

Figure 2. Percentage of cell life in MTT assay

Table 2. The anti-inflammatory properties of coconut shell of liquid smoke (CS-LS) in carrageenan-induced paw edema

\begin{tabular}{lccc}
\hline \multirow{2}{*}{ Group } & \multicolumn{3}{c}{ Paw edema* } \\
\cline { 2 - 4 } & $\mathbf{1 5}$ minutes & $\mathbf{4 5}$ minutes & 60 minutes \\
\hline Control & $3.90 \pm 1.73$ & $14.08 \pm 3.09$ & $23.56 \pm 7.51$ \\
Indomethacin & $3.24 \pm 1.29$ & $11.42 \pm 3.97$ & $19.60 \pm 3.16$ \\
CS-LS 1\% & $5.62 \pm 0.72$ & $12.43 \pm 4.08$ & $21.72 \pm 12.19$ \\
CS-LS 2\% & $5.54 \pm 2.27$ & $12.32 \pm 1.19$ & $21.58 \pm 3.63$ \\
CS-LS 4\% & $5.61 \pm 1.39$ & $11.60 \pm 3.67$ & $21.32 \pm 8.17$ \\
CS-LS 6\% & $5.69 \pm 2.16$ & $11.36 \pm 4.40$ & $21.27 \pm 5.64$ \\
CS-LS 8\% & $5.27 \pm 2.48$ & $11.23 \pm 2.32$ & $20.82 \pm 4.24$ \\
CS-LS 10\% & $5.08 \pm 2.79$ & $11.11 \pm 4.88$ & $20.67 \pm 8.88$ \\
CS-LS 12\% & $5.04 \pm 1.56$ & $10.97 \pm 2.02$ & $20.52 \pm 3.77$ \\
CS-LS 14\% & $4.52 \pm 2.36$ & $10.79 \pm 1.77$ & $20.40 \pm 4.79$ \\
CS-LS 100\% & $5.71 \pm 3.45$ & $11.46 \pm 3.42$ & $20.57 \pm 2.24$ \\
\hline
\end{tabular}

*Each value represents mean \pm SD (\%) volume of paw edema. 
Table 3. The anti-nociceptive properties of coconut shell of liquid smoke (CS-LS) in hot-plate method

\begin{tabular}{|c|c|c|c|}
\hline \multirow{2}{*}{ Group } & \multicolumn{3}{|c|}{ Licking reaction* } \\
\hline & 30 minutes & 45 minutes & 60 minutes \\
\hline Control & $5.50 \pm 0.58^{g}$ & $6.00 \pm 0.82^{\mathrm{e}}$ & $5.75 \pm 0.50$ \\
\hline Tramadol & $17.50 \pm 1.29^{a, b, c, c, d, f, f g}$ & $19.25 \pm 1.71^{\mathrm{a}, \mathrm{b}, \mathrm{c}, \mathrm{d}, \mathrm{e}}$ & $22.50 \pm 2.08^{a, b, c, d, d, f, f, h}$ \\
\hline CS-LS 1\% & $7.50 \pm 0.58^{b, \#}$ & $7.75 \pm 0.50^{\mathrm{a}, \#}$ & $8.00 \pm 0.82^{\mathrm{a}, \#}$ \\
\hline CS-LS $2 \%$ & $8.00 \pm 0.82^{c, \#}$ & $8.00 \pm 0.82^{b, \#}$ & $8.00 \pm 0.82^{\mathrm{b}, \#}$ \\
\hline CS-LS 4\% & $9.25 \pm 0.50^{\mathrm{d}, \#}$ & $10.00 \pm 2.45^{c, \#}$ & $10.50 \pm 1.00^{c, \#}$ \\
\hline CS-LS 6\% & $11.50 \pm 0.58^{\mathrm{e}, \#}$ & $12.25 \pm 0.96^{\mathrm{d}, \#}$ & $12.75 \pm 0.96^{\mathrm{d}, \#}$ \\
\hline CS-LS 8\% & $15.25 \pm 0.50^{\mathrm{f}, \#}$ & $16.75 \pm 1.26^{\#}$ & $17.75 \pm 0.96^{e}$ \\
\hline CS-LS 10\% & $16.00 \pm 0.82$ & $17.00 \pm 0.82$ & $18.00 \pm 0.82^{f}$ \\
\hline CS-LS $12 \%$ & $16.75 \pm 1.50$ & $17.50 \pm 1.73$ & $18.25 \pm 1.71^{\mathrm{g}}$ \\
\hline CS-LS $14 \%$ & $17.25 \pm 1.89$ & $18.25 \pm 1.50$ & $18.75 \pm 2.63^{h}$ \\
\hline CS-LS $100 \%$ & $18.75 \pm 1.50^{\#}$ & $19.50 \pm 0.58^{\#}$ & $18.75 \pm 2.63^{\#}$ \\
\hline
\end{tabular}

*Each value represents mean \pm SD (s) licking behavior as thermal pain reaction.

Same character and symbol in every value is considered as significantly different with ANOVA and LSD test with $P$ value $<0.01$.

The CS-LS showed lower thermal pain reaction compared with tramadol after 60 minutes of administration $(P=0.001)$. The CS-LS $100 \%$ has higher thermal pain reaction compared to CS-LS $1 \%-6 \%(P=0.001)$.

Oral ulcer healing properties

The oral ulcer healing ability was measured based on the number of fibroblasts in the oral ulcer tissue stained with hematoxylin-eosin. The fibroblast was calculated on the edge of the ulcer (blue box). The number of fibroblasts after giving CS-LS topically for three days, five days, and seven days is presented in Figures 3, 4, and 5, respectively.

Fibroblast number in the oral ulcer after treating with CS-LS 100\% was higher compared with the control group after treatment for three $(P=0.002)$, five $(P=0.001)$ and seven days $(P=0.002)$. When compared with CS-LS $8 \%$, the fibroblast number was lower after seven days $(P=0.001)$ (Figure 6).

\section{Discussion}

This study was aimed to evaluate the characteristics, cytotoxicity, anti-inflammation, anti-nociceptive, and ulcer healing properties of CS-LS after storage. In a previous study, CS-LS obtained from the pyrolysis process had a yellow color, acidity 2.39 , and density of $1.0643 \mathrm{~g} / \mathrm{mL}$. After 5 years storage of CS-LS in $5^{\circ} \mathrm{C}$, these characteristics were the same (yellow color, acidity 2.29 , and density of $1.0102 \mathrm{~g} / \mathrm{mL}$ ). The lower temperature was able to maintain the physical characteristics and physicochemical properties of CS-LS. Research conducted by Piccirilli et al confirmed that incorporating the liquid smoke with whey protein concentration was able to maintain the physicochemical properties after stored 28 days in $8^{\circ} \mathrm{C}$ compared to $25^{\circ} \mathrm{C}$ (16). This result may also confirm that the lower temperature is better at maintaining the physical characteristic and physicochemical properties of CS-LS itself.

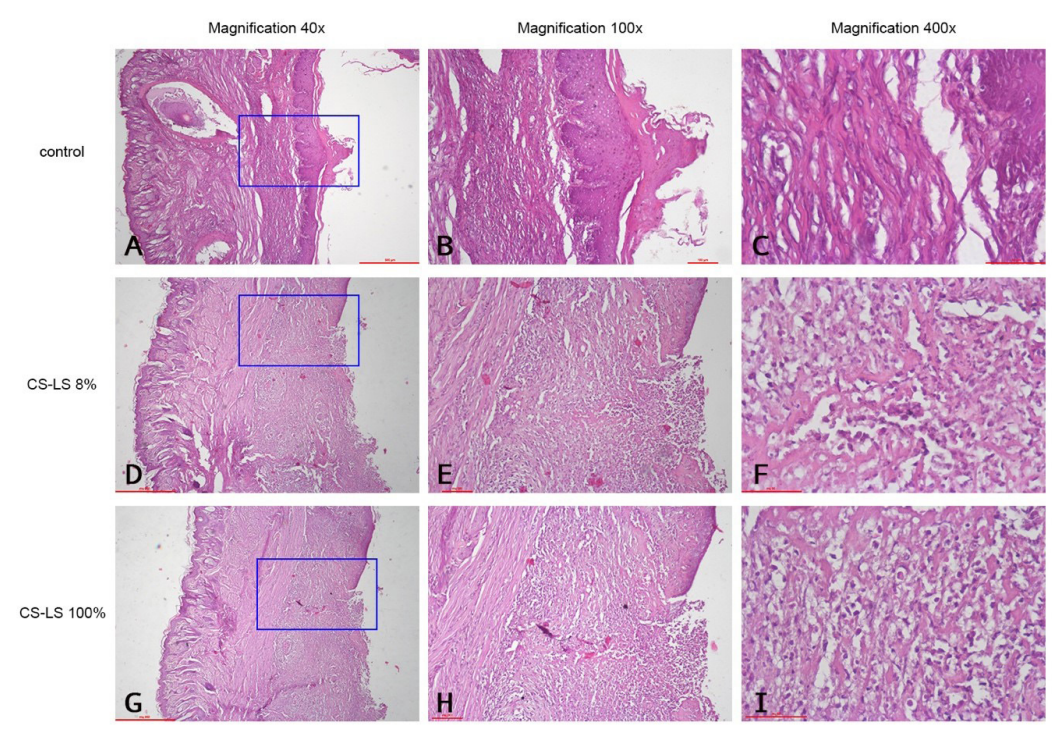

Figure 3. The fibroblast number after 3 days. The fibroblast was calculated in the edge of the ulcer (blue box). 


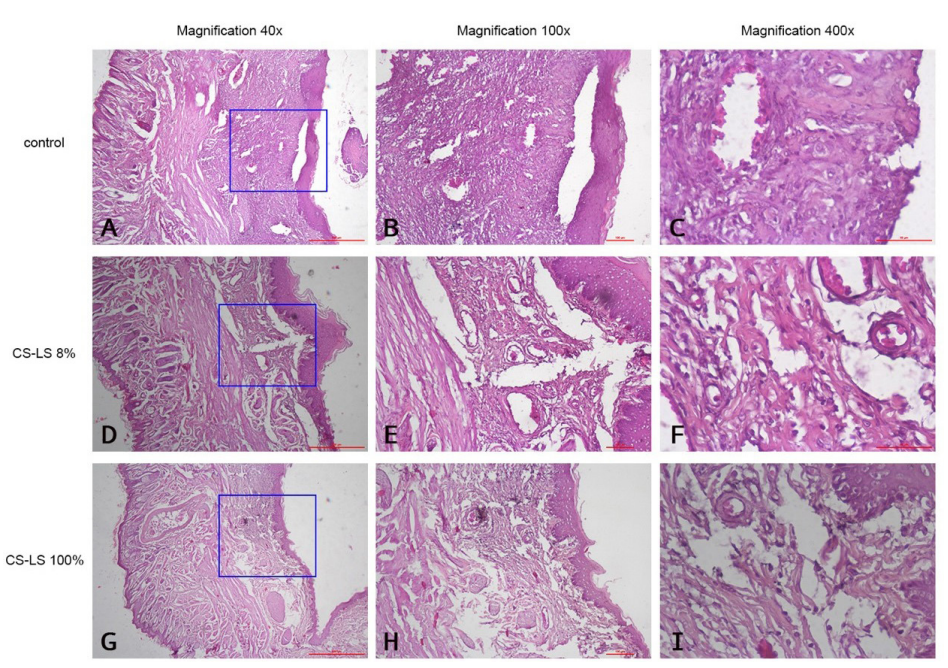

Figure 4. The fibroblast number after 5 days. The fibroblast was calculated in the edge of the ulcer (blue box).

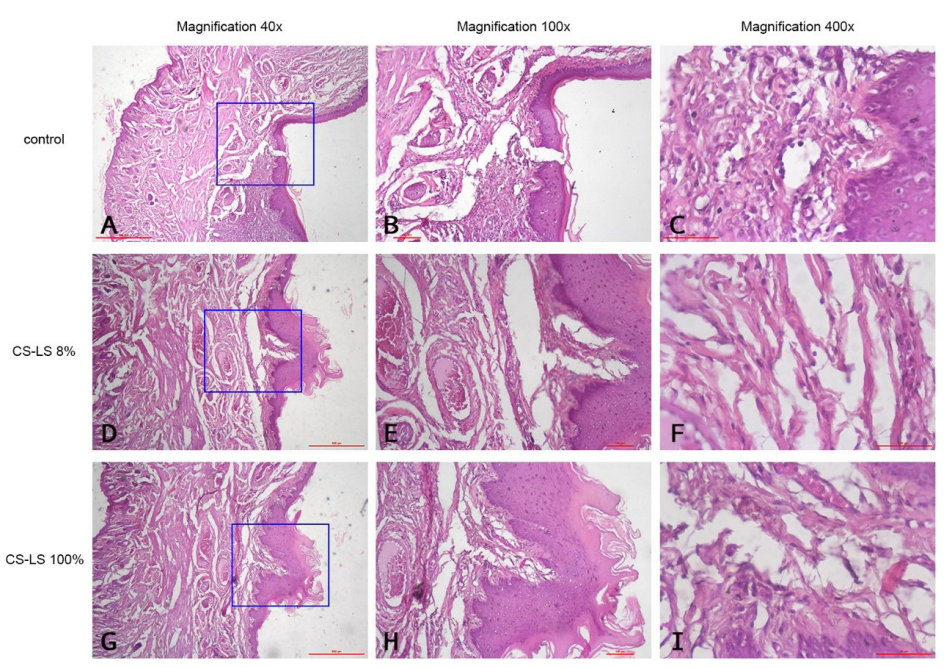

Figure 5. The fibroblast number after 7 days. The fibroblast was calculated in the edge of the ulcer (blue box).

The quality of liquid smoke is determined by phenolic compound and lower acidity because that characteristics could determine the antibacterial effect in food preservation (17). The lower acidity is caused by formic acid, acetic acid, and furfural (18). The phenolic compound, polyaromatic hydrocarbon and lower acidity have allegedly played an important role in liquid smoke toxicity (19). Based on these reasons, the safety of liquid smoke needs to be investigated because of its relevance to human health (20).

The major phenolic compounds identified in the CSLS were such as phenol (32.75\%), 2-methoxy-phenol (guaiacol) (17.45\%), and furfural (13.09\%). This structure has $\mathrm{OH}^{-}$or hydroxyl structure (21). $\mathrm{OH}$ - structure has a high quantitative structure-activity relationship and $\mathrm{OH}^{-}$ bond dissociation enthalpy. Both of these characteristics are responsible for inducing toxicity, because $\mathrm{OH}^{-}$can be deposited into the membrane cells, transported into cells by cellular transport, processing the toxicity (20). The process of toxicity to cells through apoptosis mechanism is by generating excessive intracellular ROS production (22). The excessive intracellular ROS production can induce G1-cell cycle arrest by upregulating p21 expression (23), activating p53 (24), and regulating the nuclear factor kappa B (NF- $\kappa \mathrm{B}$ ) activity (25). On the other hand, phenolic compounds in the CS-LS act as antioxidants. The antioxidant activity of CS-LS is thought to inhibit or reduce free radicals by transferring hydrogen atoms from their hydroxyl groups. A phenolic compound with peroxyl radical (ROO-) reaction mechanism involves a coordinated shift of the hydrogen cation from the phenol to the radical, creating a transition state of an $\mathrm{H}-\mathrm{O}$ bond with one electron (26).

In a previous study, the important CS-LS compounds identified were phenol (36.6\%), 2-methoxy-phenol $(25.2 \%)$ and furfural (17.09\%) (1). The composition had 


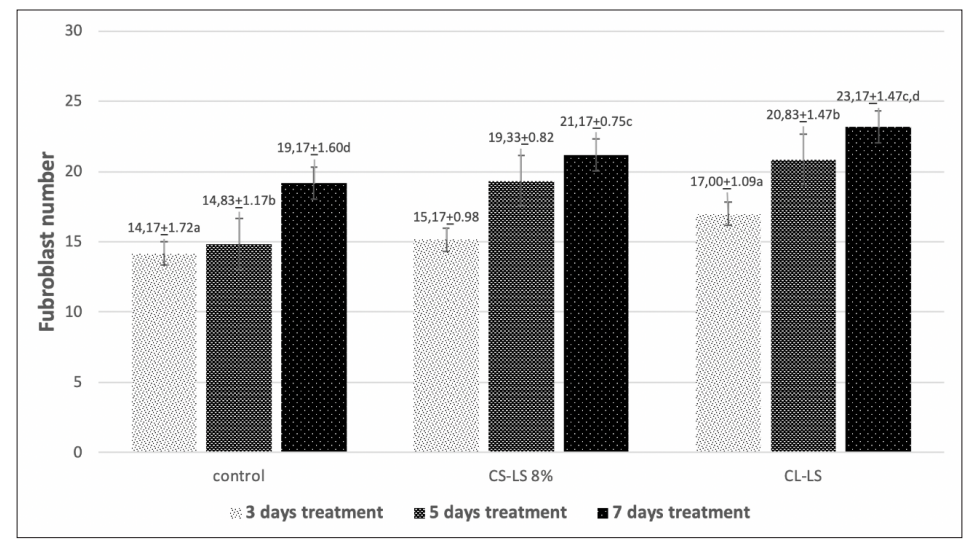

Figure 6. The fibroblast number in oral ulcer tissue after coconut shell of liquid smoke (CS-LS) treatment. The same character in the top of bar indicated the significant number with ANOVA and LSD test with $P<0.01$.

no significant difference with the CS-LS in this study after 5 years of storage.

In the present study, CS-LS 100\% and CS-LS $8 \%$ showed safe concentrations by an in-vitro toxicity test. The CS-LS $10 \%, 12 \%$, and $14 \%$ showed lower living cells of BHK21 less than $60 \%$ and considered toxic concentrations. At low concentrations, the phenolic compounds activate the mitogen-activated protein kinase, leading to the expression of genes provoking protective mechanisms leading to gene expressions, which trigger protective mechanisms. Nevertheless, these compounds additionally activated the caspase pathway by increasing the phenolic concentrations, contributing to apoptosis (21). Even though the cytotoxicity data of after-process of CS-LS were not available, its therapeutic potentials have been proven (3). There is no relevant data that revealed in-vivo toxicity tests of after-process of CS-LS. Based on the lack of data, the toxicity of after-process and after-storage CSLS cannot be compared. But, in the present study, it is confirmed that the after-storage CS-LS showed no toxicity of CS-LS $100 \%$ and CS-LS $8 \%$.

The concentrations of CS-LS $1 \%$ to CS-LS 14\% (except CS-LS 8\%) showed the toxicity properties. The toxicity of CS-LS can be related to phenolic compounds and polyaromatic hydrocarbons. The phenolic compound that has a relationship with toxicity is phenol. In a study, $60 \mathrm{mg} /$ $\mathrm{kg}$ of phenol exhibited toxicity in an animal model (27). A study confirmed that the liquid smoke from rice hulls had components similar to CS-LS, and had no toxicity at doses of 50,500,5000, and $15000 \mathrm{mg} / \mathrm{kg}$ body weight (28). A study showed that the doses of phenol around $10-15 \mathrm{mg} / \mathrm{L}$ had toxicity (29). Nevertheless, the CS-LS 1\% as the lowest concentration, effectively prevented the growth of bacteria such as Escherichia coli, and Salmonella and prevented the production of histamine $(30,31)$.

A previous study demonstrated the anti-nociceptive properties of CS-LS. The CS-LS 100\% had better antinociceptive properties compared to the CS-LS 50\% and CS-LS 25\% in the model of acetic acid-induced writhing reflex (13), the same as this study.

The possible mechanism is that phenolic compounds inhibit tissue cyclooxygenase reducing the synthesis of prostaglandin $\mathrm{E}_{2}$. The reduced number of prostaglandins could disrupt the main transduction mechanisms of the afferent nociceptor, inhibiting pain response (13).

CS-LS has the ability to increase the oral ulcer healing in diabetic (3) by increased macrophages (4), decreased pro-inflammatory cytokine (1), increased the fibroblast, growth factor (6), and collagen synthesis (5). In this study, we showed the properties of CS-LS to stimulate oral ulcer healing after 5 years of storage. The CS-LS $100 \%$ and CSLS $8 \%$ were able to stimulate fibroblasts after treatment for three, five and seven days. The possible mechanism is related to the stable physical characteristic of CS-LS (Acidity, density, and phenolic compounds). The phenolic compounds, especially phenol and guaiacol, are able to inhibit NF- $\kappa B$ expression in macrophages (4) and decrease the released pro-inflammatory cytokines such as TNF- $\alpha$ (1). The reduction of inflammation will enhance the release of growth factors such as fibroblast growth factor and vascular endothelial growth factor (6) to increase fibroblast proliferation and collagen synthesis (5). Another mechanism involved in the increased fibroblast proliferation is the inhibition of ROS production by phenol and guaiacol. The inhibition of ROS production will inhibit the activation of the FOXO1 transcription factor to increase caspase-3 that has an important role in fibroblast apoptosis (32). This process will increase the number of fibroblasts during oral ulcer healing

Based on the present results it possesses anti-nociceptive activity. This research confirms that the right temperature will maintain the properties of CS-LS and proves its antinociceptive, non-toxic, and oral ulcer healing properties.

\section{Conclusion}

After-storage CS-LS showed a high level of acidity. The CS-LS $100 \%$ was the optimum concentration for nontoxicity properties, anti-nociceptive and oral ulcer 
healing properties. The CS-LS 100\% showed potent antinociceptive, but not for the anti-inflammation. The CSLS is a promising natural herb for various medicinal uses, especially for oral ulcer therapy. The future research is needed to compare after-processed CS-LS and after storage CS-LS in-vivo model in the same time and concentrations to confirm its potential in oral ulcer healing.

\section{Authors' contributions}

MDCS got the funding, wrote the draft of manuscript, data analysis, conceived and performed the experiments; FYM performed the experiments; NFA wrote the draft of manuscript; ABRS revised the manuscript and language correction; DSE revised the manuscript; DM revised the manuscript; IA revised the manuscript; AABN performed the experiments; IPR performed the experiments. All authors read and confirmed publication of the paper.

\section{Conflict of interests}

All authors declare no conflict of interest related to this manuscript.

\section{Ethical considerations}

This study was conducted in full compliance with the Guide for the Care and Use of Laboratory Animals, in National Health Research and Development Ethics Standard and Guidelines Council (2017), Minister of Health, Republic of Indonesia. The study was approved on February 05, 2020, by the Ethical Committee of Health Research, Faculty of Dental Medicine, Universitas Airlangga (registered number: 047/HRECC.FODM/ II/2020).

\section{Funding/Support}

This study was funded by Faculty of Dental Medicine - Universitas Airlangga 2020 in the schema Penelitian Dosen Pemula (PDP) with grant number 1618/UN3.1.2/ $\mathrm{PT} / 2020$.

\section{References}

1. Surboyo MDC, Arundina I, Rahayu RP, Mansur D, Bramantoro T. Potential of distilled liquid smoke derived from coconut (Cocos nucifera L) shell for traumatic ulcer healing in diabetic rats. Eur J Dent. 2019;13(2):271-9. doi: 10.1055/s-0039-1693527.

2. Nopriardy F, Mulyadi H, Setiaji B. Liquid smoke: rebung preservation in canned food for ASEAN food marketing. KnE Soc Sci. 2018;3(5):239-52.

3. Surboyo MD, Ernawati DS, Arundina I, Rahayu RP. Oral ulcer healing after treatment with distilled liquid smoke of coconut shell on diabetic rats. J Krishna Inst Med Sci Univ. 2019;8(2):70-9.

4. Surboyo MDC, Mahdani FY, Ernawati DS, Sarasati A, Rezkita F. The macrophage responses during diabetic oral ulcer healing by liquid coconut shell smoke: an immunohistochemical analysis. Eur J Dent. 2020;14(3):4104. doi: 10.1055/s-0040-1712776.
5. Surboyo MD, Arundina I, Rahayu RP. Increase of collagen in diabetes-related traumatic ulcers after the application of liquid smoke coconut shell. Dent J (Maj Kedokt Gigi). 2017;50(2):71-5. doi: 10.20473/j.djmkg.v50.i2.p71-75.

6. Ayuningtyas NF, Dwi M, Surboyo C, Ernawati DS, Parmadiati AE. The role of liquid smoke coconut shell in the proliferation phase of an oral traumatic ulcer. J Pharm Pharmacogn Res. 2020;8(6):549-57.

7. Widowati L, Nurhayati. The use of traditional health care among Indonesian family. Health Sci J Indones. 2017;8(1):30-5. doi: 10.22435/hsji.v8i1.5600.

8. de Souza JLS, da Silva Guimarães V, Campos AD, Lund RG. Antimicrobial potential of pyroligneous extracts - a systematic review and technological prospecting. Braz J Microbiol. 2018;49 Suppl 1:128-39. doi: 10.1016/j. bjm.2018.07.001.

9. Tarawan VM, Mantilidewi KI, Dhini IM, Radhiyanti PT, Sutedja E. Coconut shell liquid smoke promotes burn wound healing. J Evid Based Complementary Altern Med. 2017;22(3):436-40. doi: 10.1177/2156587216674313.

10. Zhang J, Onakpoya IJ, Posadzki P, Eddouks M. The safety of herbal medicine: from prejudice to evidence. Evid Based Complement Alternat Med. 2015;2015:316706. doi: $10.1155 / 2015 / 316706$.

11. Maga JA. Smoke in Food Processing. New York: CRC Press; 2018. p. 1-155.

12. Budijanto S, Hasbullah R, Prabawati S, Zuraida I. Identifikasi dan uji keamanan asap cair tempurung kelapa untuk produk pangan. J Pascapanen. 2008;5(1):32-40. doi: 10.21082/jpasca.v5n1.2008.32-40.

13. Surboyo MDC, Tantiana T, Arundina I. Analgesic effect of coconut shell (Cocos nucifera L) liquid smoke on mice. Dent J (Maj Kedokt Gigi). 2012;45(3):156-60. doi: 10.20473/j. djmkg.v45.i3.p156-160.

14. Permanasari AR. The pyrolysis reactor design and the effect of liquid smoke from coconut shell on microbial contamination of tofu. Int J Appl Technol Res. 2020;1(2):128-39. doi: 10.35313/ijatr.v1i2.28.

15. Paramitha MR, Tukiran T. Cytotoxicity test of isolated compound from Syzygium malaccense stem bark on fibroblast BHK 21 cells. In: Seminar Nasional KimiaNational Seminar on Chemistry (SNK 2018). Atlantis Press; 2018. p. 76-8.

16. Piccirilli GN, Soazo M, Pérez LM, Delorenzi NJ, Verdini RA. Effect of storage conditions on the physicochemical characteristics of edible films based on whey protein concentrate and liquid smoke. Food Hydrocoll. 2019;87:221-8. doi: 10.1016/j.foodhyd.2018.08.015.

17. Handojo L, Indarto A. Cocoa bean skin waste as potential raw material for liquid smoke production. Environ Technol. 2020;41(8):1044-53. doi: 10.1080/09593330.2018.1520306.

18. Sokamte tegang A, Mbougueng PD, Sachindra NM, Douanla Nodem NF, Tatsadjieu Ngoune L. Characterization of volatile compounds of liquid smoke flavourings from some tropical hardwoods. Sci Afr. 2020;8:e00443. doi: 10.1016/j.sciaf.2020.e00443.

19. McDonald ST. Comparison of health risks of smoked foods as compared to smoke flavorings: are smoke flavors "healthier". Adv Food Technol Nutr Sci Open J. 2015;1(6):130-4. 
20. Wright JS, Shadnia H. Computational modeling of substituent effects on phenol toxicity. Chem Res Toxicol. 2008;21(7):1426-31. doi: 10.1021/tx800085a.

21. Kyselova Z. Toxicological aspects of the use of phenolic compounds in disease prevention. Interdiscip Toxicol. 2011;4(4):173-83. doi: 10.2478/v10102-011-0027-5.

22. Coccia A, Mosca L, Puca R, Mangino G, Rossi A, Lendaro E. Extra-virgin olive oil phenols block cell cycle progression and modulate chemotherapeutic toxicity in bladder cancer cells. Oncol Rep. 2016;36(6):3095-104. doi: 10.3892/ or.2016.5150.

23. Shin SY, Yoon H, Ahn S, Kim DW, Bae DH, Koh D, et al. Structural properties of polyphenols causing cell cycle arrest at G1 phase in HCT116 human colorectal cancer cell lines. Int J Mol Sci. 2013;14(8):16970-85. doi: 10.3390/ ijms 140816970 .

24. Yuan L, Zhang Y, Xia J, Liu B, Zhang Q, Liu J, et al. Resveratrol induces cell cycle arrest via a p53-independent pathway in A549 cells. Mol Med Rep. 2015;11(4):2459-64. doi: $\quad 10.3892 / \mathrm{mmr} .2014 .3100$.

25. Schwertheim S, Wein F, Lennartz K, Worm K, Schmid KW, Sheu-Grabellus SY. Curcumin induces G2/M arrest, apoptosis, NF- $\mathrm{BB}$ inhibition, and expression of differentiation genes in thyroid carcinoma cells. J Cancer Res Clin Oncol. 2017;143(7):1143-54. doi: 10.1007/s00432017-2380-z.

26. Nimse SB, Pal D. Free radicals, natural antioxidants, and their reaction mechanisms. RSC Adv. 2015;5(35):27986-
8006. doi: 10.1039/c4ra13315c.

27. Wang $\mathrm{C}, \mathrm{Xu}$ YJ, Shi Y, Wang C, Duan L, Gu W, et al. Verification on the developmental toxicity of shortterm exposure to phenol in rats. Biomed Environ Sci. 2020;33(6):403-13. doi: 10.3967/bes2020.055.

28. Arundina I, Tantiana T, Diyatri I, Surboyo MDC, Adityasari R. Acute toxicity test of liquid smoke of rice hull (Oryza sativa) on Mice (Mus musculus). J Int Dent Med Res. 2020;13(1):91-6.

29. de Moraes FD, de Figueiredo JS, Rossi PA, Venturini FP, Moraes G. Acute toxicity and sublethal effects of phenol on hematological parameters of channel catfish Ictalurus punctatus and pacu Piaractus mesopotamicus. Ecotoxicol Environ Contam. 2015;10(1):31-6.

30. Dien HA, Montolalu RI, Berhimpon S. Liquid smoke inhibits growth of pathogenic and histamine forming bacteria on skipjack fillets. IOP Conf Ser Earth Environ Sci. 2019;278:012018. doi: 10.1088/1755-1315/278/1/012018.

31. Machado GHA, Marques TR, de Carvalho TCL, Duarte AC, de Oliveira FC, Gonçalves MC, et al. Antibacterial activity and in vivo wound healing potential of phenolic extracts from jaboticaba skin. Chem Biol Drug Des. 2018;92(1):1333-43. doi: 10.1111/cbdd.13198.

32. Desta T, Li J, Chino T, Graves DT. Altered fibroblast proliferation and apoptosis in diabetic gingival wounds. J Dent Res. 2010;89(6):609-14. doi: $10.1177 / 0022034510362960$ 